\title{
Kepemimpinan dan Kepuasan Kerja Dampaknya Terhadap Kinerja Guru
}

\author{
Rita Zusana Lantu1; Tungga Buana Irfana² \\ 1Program Studi Magister Manajemen Universitas Bhayangkara Jakarta Raya \\ rita.zusana.lantu@yahoo.com \\ 2Program Studi Magister Manajemen Universitas Bhayangkara Jakarta Raya \\ tunggabuanairfana@dsn.ubharajaya.ac.id
}

\begin{abstract}
ABSTRAK
Permasalahan yang dikaji adalah bagaimana gaya kepemimpinan dan kepuasan kerja, adakah pengaruh kepemimpinan dan kepuasan kerja secara parsial maupun simultan terhadap kinerja guru. Metode pengumpulan data yang digunakan adalah metode kuesioner (angket). Metode analisis data yang digunakan dalam penelitian ini adalah metode analisis deskripsi dan regresi linier berganda. Berdasarkan hasil penelitian diperoleh persamaan regresi linier berganda. Dengan menggunakan SPSS 17 Hasil hipotesis kepemimpinan, H1 diterima ada pengaruh langsung positif gaya kepemimpinan terhadap kinerja guru, hipotesis kepuasan kerja, H2 diterima ada pengaruh langsung positif kepuasan kerja terhadap kinerja guru dan hasil hipotesis secara bersama-sama H3 ada pengaruh positif gaya kepemimpinan dan kepuasan kerja terhadap kinerja guru SMP Negeri Kecamatan Setu Kabupaten Bekasi. Kesimpulan yang dapat diambil dari hasil penelitian ini adalah bahwa terdapat pengaruh positif gaya kepemimpinan terhadap kinerja guru SMP Negeri Kecamatan Setu artinya peningkatan intensitas perilaku atau cara bertindak pemimpin dalam proses mempengaruhi, mengarahkan, menginspirasi, memotivasi dan mengkordinasi guru serta menyelenggarakan program-program peningkatan kompetensi guru akan mengakibtkan peningkatan kinerja guru SMP Negeri. Terdapat pengaruh positif kepuasan kerja terhadap kinerja guru SMP Negeri. Artinya peningkatan intensitas kepuasan kerja akan mengakibtkan peningkatan kinerja guru SMP Negeri. Terdapat pengaruh positif secara bersama-sama antara Gaya kepemimpinan dan kepuasan kerja terhadap kinerja guru SMP Negeri.

Kata Kunci:Kepemimpinan, Kepuasan Kerja, Kinerja Guru
\end{abstract}

\section{ABSTRACT}

The problem that is studied is how the leadership style and job satisfaction, whether there is any effect of leadership and job satisfaction partially or simultaneously on the teacher's performance. Data collection method that is used is the method of a questionnaire (questionnaire). The data analysis Methods that is used in this study is the description of the analysis method and the multiple linear regressions. Based on the results of research, it is obtained multiple linear regression equation. By using SPSS 17 the hypothesis leadership results, H1 is received that there is positive direct effect of leadership style on teacher's performance. The hypothesis of job satisfaction, $\mathrm{H} 2$ is received that there is positive direct effect of job satisfaction on the teachers' performance and then hypothesis together H3, There is a positive effect of leadership style and job satisfaction on the State of Junior High School teacher's performance in Setu District of Bekasi Regency. The conclusion that can be taken from this result is that there is positive effect of leadership style on the performance of the State of Junior High School teacher. It means that the increasing of the behavior intensity or the way of acting leader in the process of influencing, directing, inspiring, motivating and coordinating the teachers and organizing the programs to increase the competence of teachers that will make the improvement of performance of State of Junior High School teacher. There is a positive effect of job satisfaction on teacher's Performance of State of Junior High School. This means that the increase of the intensity of job 
satisfaction will increase teacher's performance of State of Junior High School. There is a positive effect collectively between leadership style and job satisfaction of the teacher's performance of state Junior High School.

Keywords: Leadership, Job Satisfaction, Teacher's Performance

Diterima: 4 Jan 2019; Direvisi: 19 Mar 2019; Diterbitkan: 15 April 2019

\section{PENDAHULUAN}

Dunia pendidikan di negara kita mulai memasuki abad ke-21, bergerak sangat cepat bersama arus globalisasi. Kondisi ini melahirkan masyarakat yang ber-etos kerja di pendidikan, jasa dan industri lainnya dengan ciri-ciri ber- orientasi ke masa depan, menjunjung tinggi individualitas dan interdependensi, integritas tatanan hidup, sadar akan peran keduniaan, kepercayaan kepada nilai kerja dan aktivisme, menjunjung tinggi iptek, integritas kebangsaan dan profesionalisme yang tinggi.

Perkembangan yang berkaitan dengan pendidikan nasional dan globalisasi mendorong kita untuk melakukan identifikasi dan mencari titik-titik simetris sehingga bisa mempertemukan dua hal yang tampaknya paradoksial, yaitu pendidikan Indonesia yang berimplikasi nasional dan global. Dampak globalisasi memaksa banyak negara meninjau kembali wawasan dan pemahaman mereka terhadap konsep bangsa, tidak saja karena faktor batas-batas territorial geografis, tetapi juga aspek ketahanan kultural serta pilar-pilar utama lainnya yang menopang eksistensi mereka sebagai nation state yang tidak memiliki imunitas absolut terhadap intrusi globalisasi. Globalisasi bisa dianggap sebagai penyebaran dan intensifikasi dari hubungan ekonomi, sosial, dan kultural yang menembus sekat-sekat geografis ruang dan waktu. Dengan demikian, globalisasi hampir melingkupi semua hal; berkaitan dengan ekonomi, pendidikan, politik, kemajuan teknologi, informasi, komunikasi, transportasi, dan lain-lain

Peningkatan mutu pendidikan di era globalisasi ini belum tergambar seutuhnya, banyak permasalahan yang melatarbelakanginya sehingga menjadi sorotan diberbagai kalangan, permasalahan yang dibahas sering terkait dengan kinerja guru dalam kegiatan belajar mengajar di kelas. Meningkatnya mutu pendidikan di sekolah sangat ditentukan oleh kesiapan dan tanggung jawab pendidik (guru) serta tenaga kependidikan sebagai komponen sumber daya manusia yang mengelolah sehingga terselenggarannya proses pendidikan. Hal ini sesuai dengan penjelasan Peraturan Pemerintah Nomor 19 Tahun 2005 tentang Standar Nasional Pendidikan dimana ada salah satu standar yang dinilai langsung berkaitan dengan pencapaian mutu lulusan (peserta didik) yaitu standar pendidik dan tenaga kependidikan. Ini berarti bahwa untuk dapat mencapai mutu lulusan yang diinginkan, mutu tenaga pendidik (guru), dan tenaga kependidikan (kepala sekolah, pengawas, laboran, pustakawan, tenaga administrasi, pesuruh) harus ditingkatkan

Sebagai seorang guru disalah satu SMP Negeri Kecamatan Setu Kabupaten Bekasi, penulis secara langsung maupun tidak langsung menjadi pelaksana dalam proses belajar mengajar di sekolah dan profesi keguruan ini telah dilaksanakan oleh penulis hampir lebih mencapai kurun waktu tujuh tahun. Proses belajar mengajar merupakan suatu proses penting yang berkaitan secara berkesinambungan antara perbuatan guru dan peserta didik sehingga merupakan suatu hubungan timbal balik yang dilaksanakan dalam situasi edukatif untuk mencapai tujuan yang sudah ditetapkan.

Didasarkan pada profesi guru dan pengalaman mengajar sebagai guru, maka penulis mendapatkan serta merasakan secara langsung berbagai permasalahan yang berkaitan dengan situasi dan kondisi guru dalam melaksanakan kegiatan belajar. Kenyataan yang terlihat di tempat penelitian adalah masih terdapat beberapa guru yang belum melaksanakan kegiatan pembelajaran 
dengan maksimal seperti yang telah diamanatkan dalam undang- undang di atas tentang pelaksanaan kinerja guru, hal ini didukung pula oleh percakapan langsung penulis dengan Pengawas Pembina SMP Negeri Kecamatan Setu tentang pelayanan kinerja guru dalam kegiatan belajar mengajar yang meliputi kemampuan merencanakan pembelajaran, melaksanakan kegiatan pembelajaran dan menilai hasil belajar adalah sebagai berikut: "Dari hasil penilaian kinerja guru di SMP Negeri se-Kecamatan Setu masih terdapat beberapa sekolah yang belum mencapai nilai yang diharapkan dan hal ini dibuktikan dengan pemenuhan persyaratan kerja guru dalam pelaksanaan kegiatan belajar mengajar masih belum mencapai harapan atau masih belum tergambar secara utuh, sekitar 30\% guru belum mempersiapkan persyaratan kerja, begitu pula dengan hasil observasi terhadap penilaian guru dalam melaksanakan proses pembelajaran masih belum maksimal, penerapan metode mengajar masih bersifat konvensional, bahkan lebih sering menggunakan metode ceramah daripada berinovasi menciptakan metode atau teknik mengajar yang efektif dan efesiensi."

Apa yang disampaikan oleh pengawas pembina di atas pada kenyataannya tergambar pada hasil pengamatan penulis di tempat penelitian dan selain itu penulis melakukan percakapan dengan rekan guru ketika selesai melaksanakan proses pembelajaran dan yang diperbincangkan adalah mengenai pelaksanaan perencanaan kegiatan belajar mengajar, sebagai berikut: "Banyak hal yang belum saya pahami dalam menerapkan indikator perencanaan pembelajaran seperti menganalisis pembelajaran, mengidenntifikasi karateristik siswa, mengembangkan butir-butir tes dan hal ini menjadi kendala dalam melaksanakan kegiatan belajar mengajar, selain itu penyedian sarana sekolah belum mamadai". Hal yang senada diperbincangkan pula oleh rekan guru yang lain: "Pelajaran saya masih menerapkan kurikulum tiga belas, tetapi ironisnya di sekolah kita menggunakan kurikulum berkarakter, hal ini membuat saya binggung mempersiapkan perencanaan pembelajaran."

Berdasarkan pengamatan penulis dan percakapan dengan rekan guru di tempat penelitian, dapat digambarkan bahwa hampir lebih $40 \%$ guru mengalami kesulitan mengembangkan pengelolaan perencanaan pembelajaran dan hal tersebut membuat guru lebih cenderung melakukan improvisasi tanpa berlandaskan pada acuan/pedoman yang jelas.

Kinerja utama guru terlihat pula pada kemampuan guru melaksanakan kegiatan belajar mengajar dan merupakan hal terpenting dalam proses pembelajaran. Dari hasil pengamatan penulis di tempat penelitian mengambarkan keterampilan professional guru yang berkaitan dengan melaksanakan pembelajaran yang mengacu kepada tugas profesional guru dalam mengelolah atau menciptakan tahapan pembelajaran yang efektif dan efisiensi yang terdiri dari tiga kegiatan pokok dalam melaksanakan proses pembelajaran yaitu : membuka pembelajaran, mengelolah pembelajaran dan menutup pembelajaran dan diimbangi dengan keterampilan menyampaikan materi dengan berbagai media, metode, sumber belajar serta berbagi faktor pendukung lainnya belum tergambar secara utuh atau pencapainnya berkisar $60 \%$.

Dari hasil percakapan dengan rekan guru terdapat beberapa faktor yang menyebabkan ketrampilan guru dalam melaksanakan pembelajaran belum maksimal, sebagai berikut: "Kendala saya dalam melaksanakan pembelajaran adalah kurangnya media atau sarana pendukung belum memadai, seharusnya sarana dan media seperti in fokus, komputer dipersiapkan sekolah sesuai dengan kebutuhan tetapi kenyataan yang ada fasilitas tersebut sangat kurang sehingga banyak materi yang sepertinya belum mampu dipahami siswa dengan baik hal ini terlihat pada pencapaian nilai yang diperoleh siswa. Saya belum bisa menerapkan program komputer dan internet karena belum sanggup membeli perangkat tersebut, ada keinginan untuk membeli tetapi bagaimana dengan biaya kebutuhan primer saya?"

Sedangkan kemampuan guru dalam melaksanakanakan diskusi kelas, memberikan motivasi, memberikan informasi pelajaran dengan komukatif, mencarikan solusi terhadap 
kesulitan materi, menggunakan alat peraga dan memberikan respon terhadap pertanyaan siswa mencapai $80 \%$, begitupula dengan ketersiapan media, sarana, dan alat peraga yang memadai belum tergambar di beberapa sekolah tempat penelitian, seperti kekuranganruang belajar, belum memiliki ruang dan fasilitas laboratorium IPA dan laboratorium bahasa. Menggunakan waktu yang efektif serta disiplin dalam melaksanakan pembelajaran belum optimal, hal yang teramati adalah ketika terjadi proses pembelajaran guru lebih sering memerintahkan siswa menulis dengan panduan buku paket tanpa menerapkan metode atau teknik pembelajaran yang efektif atau guru lebih sering tidak berada di ruang kelas, kenyataan ini menggambarkan bahwa guru belum maksimal mengelolah dan menguasai kelas dengan baik ketika terjadi proses pembelajaran. Hasil percakapan penulis dengan rekan guru dan siswa menguatkan kondisi tersebut: "Ketika mengajar siswa hampir lebih sering ribut dan saya selalu memperingatkan mereka agar tenang dan yang paling mengecewakan siswa tidak mendengarkan apa yang saya sampaikan. Jam pelajaran ke tiga, ada beberapa teman yang berkelahi karena Bu guru tidak berada di kelas. Tadinya masuk kelas tetapi keluar lagi dengan alasan menjemput anaknya di sekolah."

Kinerja guru terkait pula dalam menilai pembelajaran yang meliputi kemampuan menilai dengan menggunakan instrument penilaian yang telah dikembangkan pada waktu merencanakan pembelajaran, dari hasil pengamatan dan percakapan langsung dengan rekan guru menggambarkan kemampuan guru pada aspek tersebut ketercapaiannya belum maksimal berkisar 60\%, tetapi kemampuan guru dalam melakukan teknik penskoran dan memberikan masukan serta melakukan tidak lanjut dalam proses perbaikan dan pembelajaran remedial mencapai 65\%. Berikut ini hasil percakapan dengan rekan guru yang mengalami kesulitan dalam mengembangkan proses penilaian yang tepat: "Metodologi perhitungan penskoran ada baiknya disosialisasi oleh pimpinan agar semua guru mengacu pada penskoran yang baku hal inilah yang membuat saya kesulitan melakukan penilaian."

Menurunnya kemampuan guru dalam melaksanakan proses pembelajaran seperti yang diuaraikan di atas mengindikasikan bahwa terdapat permasalahan dalam kinerja guru dan akan mempengaruhi pencapaian hasil belajar siswa dan pembentukan karakter siswa, hal ini diperjelas oleh pernyataan rekan guru yang mengeluhkan tentang pencapaian nilai KKM untuk mata pelajarannya belum sesuai dengan standart yang diharapkan bahkan terdapat nilai mata pelajarannya di satu kelas yang berjumlah empat puluh siswa pencapaian jumlah nilai hasil belajar (nilai roport) merata yaitu tidak melebihi standart nilai KKM. Selain itu teramati pula perilaku siswa yang tidak diharapkan seperti membolos, berkelahi di kelas, bahkan melakukan tawuran dengan siswa dari sekolah yang lain, hal lain yang teramati serta didasarkan pada data daftar hadir siswa menunjuk ketidakhadiran siswa selama satu semester melebihi standar yang ditetapkan.

Dari hasil pengamatan penulis dan percakapan langsung dengan rekan guru menggambarkan bahwa perilaku kepemimpinan kepala sekolah masih belum dapat mengoptimalkan segenap peran yang diembannya, dan hal yang teramati adalah pemimpin belum menunjukkan perilaku yang sesuai dengan apa yang diharapkan guru seperti memperhatikan dan mengevaluasi sarana prasarana yang masih kurang dan yang tidak memadai, penyedian sumber belajar yang terbatas, pemimpin belum mampu mengembangkan pola pikir guru agar bekerja dengan baik, peningkatan profesionalisme guru belum merata, dan kesejahtraan guru belum menjadi prioritas kepala sekolah, hal ini terungkap melalui hasil percakapan penulis dengan guru: "Pemimpin sebaiknya memberi pengaruh yang positif melalui perilaku dan sosialisasi mengembangkan keterampilan guru, masih banyak teman guru yang berharap diikutsertakan dalam pelatihan, bersikap adil kepada semua guru itulah harapan guru, tetapi yang terlihat hampir lebih sering kepala sekolah tidak berada di sekolah dan menggambil keputusan secara sepihak. 
Pernyataan yang senada disampaikan pula oleh rekan guru yang lain: "Menurunnya semangat mengajar beberapa guru dikarenakan kurangnya kebebasan guru memberikan pendapat atau masukan demi kemajuan sekolah. Selain itu keadilan yang merata kepada guru belum terlihat khususnya dalam mengembangkan keterampilam profesi guru dan pemenuhan hak-hak guru belum diperhatikan, seperti menaikan gaji guru honor seperti di sekolah lain, apalagi saat ini biaya kebutuhan hidup meningkat."

Kenyataan yang terlihat di tempat penelitian menunjukan sikap ketidakperdulian kepala sekolah terhadap kebutuhan proses pembelajaran guru masih terlihat seperti penyedian saranasekolah yang tidak sesuai dengan kebutuhan guru dan siswa, bahkan sarana dan prasarana yang tidak memadai atau mengalami kerusakan masih terlihat di ruang kelas, ruang tata usaha, ruang perpustakaan bahkan ruang guru.

Menurunnya kinerja guru serta perilaku kepala sekolah yang belum begitu perduli dengan situasi kondisi guru akan mempengaruhi faktor kepuasan kerja dalam guru melaksanakan proses pembelajaran. Hal yang teramati adalah keterlambatan pembayaran gaji/insentif guru honoher, tunjangan kinerja guru dan tunjangan profesi guru PNS, bahkan sampai saat ini dibeberapa tempat penelitian gaji guru honorerbelum sesuai dengan standart kebutuhan hidup. Kondisi seperti ini menjadi salah satu penyebab ketidakpuasan guru mengajar sehingga mengakibatkan menurunnya kinerja guru dalam melaksanakan proses pembelajaran, hal ini terungkap dari hasil percakapan rekan guru dengan penulis, sebagai berikut: "Saya sangat mencintai pekerjaan guru tetapi hampir lima tahun mengabdi di sekolah ini gaji yang saya terima belum mencukupi kebutuhan hidup saya dan keluarga, hal inilah yang membuat saya mencari pekerjaan tambahan, agar terpenuhi kebutuhan keluaga."

Mencintai pekerjaan serta memiliki kemampuan profesionalisme guru akan memberikan kepuasan dalam guru melasanakan proses pembelajaran, tetapi yang teramati masih banyak rekan guru yang tingkat pendidikannya belum sesuai dengan standart kompetensi keguruan, beberapa guru di tempat penelitian belum memenuhi persyaratan minimal tingkat pendidikan strata satu (S1) dan hal ini akan mempengaruhi kepuasan guru dalam melaksanakan proses pembelajaran. Tetapi dari hasil pengamatan dan percakapan dengan rekan guru memperlihatkan masih terdapat rasa puas guru atau perasaan senang guru dalam melaksanakan proses pembelajaran, yaitu hubungan guru dengan sesama rekan gurusangat baik artinya sikap perduli, saling menghargai, tolong menolong, dan toleransi berjalan dengan baik dan pengakuan rekan guru dan pimpinan atas hasil kerja guru sering terlihat.

Penelitian ini secara optimal bertujuan untuk mendeskripsikan dan menganalisis halhal sebagai berikut: untuk mengetahui pengaruh dari faktor kepemimpinan terhadap kinerja guru di SMP Negeri Kecamatan Setu, Kabupaten Bekasi; untuk mengetahui pengaruh dari faktor kepuasan kerja terhadap kinerja guru di SMP Negeri Kecamatan Setu, Kabupaten Bekasi; dan untuk mengetahui pengaruh dari faktor kepemimpinan dan kepuasan terhadap kinerja guru di SMP Negeri Kecamatan Setu, Kabupaten Bekasi.

\section{KAJIAN TEORETIK \\ Pengertian Kinerja}

Kinerja sumber daya manusia merupakan istilah yang berasal dari kata Job Performance atau Actual Performance (prestasi kerja atau prestasi sesungguhnya yang dicapai seseorang). Definisi kinerja karyawan adalah perbandingan hasil yang dicapai dengan peran serta tenaga kerja persatuan waktu/lazimnya per jam (Anwar Prabu, 2014: 9). Kinerja merupakan suatu istilah secara umum yang digunakan untuk sebagian atau seluruh tindakan atau aktivitas dari suatu organisasi pada suatu periode dengan referensi pada sejumlah standar sperti biaya- biaya masa lalu atau yang diproyeksikan, dengan dasar efisiensi, pertanggungjawaban atau akuntabilitas manajemen dan semacamnya. Kinerja jika hasil yang diinginkan dan diamati secara tertentu dapat terjadi dengan mengacu 
pada tingkat layanan atau kecepatan respon dan sistem kerja kinerja tinggi menyediakan sarana untuk menciptakan budaya kinerja. Perwujudannya adalah dengancara berpikir tentang kinerja dan bagaimana hal itu dapat ditingkatkan. Sistem kerja kinerja tinggi terdiri dari praktek-praktek yang dapat memfasilitasi keterlibatan karyawan, peningkatan keterampilan dan motivasi (M. Armstrong, 2009: 48).

Untuk mewujudkan kinerja handal diperlukan perhitungan kemampuan yang handal dan akan terlihat pada persepsi tugas yang merupakan petunjuk dimana timbul rasa percaya bahwa kinerja baik pegawai dapat diwujudkan melalui usaha-usaha dalam melakukan aktivitas pekerjaan. Usaha maksimal kinerja pegawai berkaitan dengan perilaku kerja yang konsisten dan komitmen dalam melaksanakan tugasnya, serta keterampilan pegawai sehingga memberi kontribusi yang besar pada organisasi dan dilaksanakan sesuai prosedur kerja, berkreativitas, dantersedianya sarana memadai akan menghasilkan produktifitas kerja yang diharapkan.

Job performance and satisfactions separate but interdependent work results. Performance is influenced by individual attributes such as ability and experience; organizational support comes from things such as goals, resources, and technology; and eff ort is the willingness of people to work hard at what they are doing. Th $e$ individual experiences satisfaction when the rewards received for work accomplishments are perceived as both performance contingent and equitable (Mary Uhl-Bien, 2014: 121).

Kinerja dipengaruhi oleh atribut individu seperti kemampuan dan pengalaman; dukungan organisasi berasal dari hal-hal seperti tujuan, sumber daya, dan teknologi; kesediaan pegawai untuk bekerja keras pada apa yang dikerjakan. Pengalaman kepuasan pegawai akan terlihat ketika menerima imbalan dengan adil sesuai dengan prestasi kerja.

Kinerja merupakan prestasi nyata yang ditampilkan seseorang setelah yang bersangkutan menjalankan tugas dan perannya dalam organisasi (Tjutju Yuniarsih dan
Suwatno, 2013:161). Pencapaian hasil kerja pegawai terlihat ketika pegawai melaksanakan kegiatan, program, kebijaksanaan guna mewujudkan visi, misi, dan tujuan organisasi yang telah ditetapkan. Hal ini menjelaskan bahwa konsep kinerja berhubungan erat dengan konsep organisasi. Kinerja pegawai yang tinggi akan memberikan sumbangsih besar kepada organisasi dalam mencapai tujuan.

Faktor-faktor yang mempengaruhi kinerja guru adalah: (Gusman, 2014:296)

1. Lingkungan kerja. Lingkungan kerja yang meyenangkan tak lepas dari tersediannya sarana prasarana yang memadai sesuai kebutuhan sehingga akan menciptakan semangat dalam bekerja dan berpengaruh terhadap hubungan antara pegawai dengan atasan maupun bawahan.

2. Motivasi kerja. Motivasi sangat penting dalam meningkatkan kinerja karena itu perlu adanya pemahaman yang baik oleh pegawai maupun pimpinan terhadap kebutuhan dan tujuan dari pekerjaan itu sendiri sehingga dapat memberikan arahan dan gambaran yang tepat untuk lebih meningkatkan motivasi dalam bekerja. Apabila motivasi dan kebutuhan bekerja sudah jelas akan memberi perubahan dan peningkatan terhadap disiplin dalam bekerja semangat bekerja serta etika dalam bekerja sehingga menghasilkan prestasi kerja.

3. Gaya kepemimpinan, merupakan carabertindak pemimpin dalam menjalankan kepemimpinan. Gaya pemimpin yang ideal disukai dan menjadi tolak ukur guru dalam menciptakan proses KBM yang efektif sehingga dapat mewujudkan pencapaian tujuan pendidikan. Gaya kepemimpinan ideal akan tercermin pada pola perilaku pemimpin (kepala sekolah) dalam bertindak atau mengambil keputusan yang didasarkan pada kondisi guru dan organisasi, melayani, menghargai, memahami serta memuhi kebutuhan guru dalam bekerja sehingga mewujudkan pencapaian kinerja guru yang maksimal dan akan memberi pengaruh terhadap proses KBM dan hasil belajar siswa. Perilaku 
pemimpin yang baik akan terlihat juga dari imbalan/insentif yang diterima guru, karena tingkat penghasilan atau gaji yang memadai dapat menimbulkan konsentrasi kerja, penyedian kualitas sarana pembelajaran akan berpengaruh pada peningkatan kinerja guru, memperhatikan penyedian dan penggunan teknologi sehingga dapat dipakai secara tepat yang akan mempercepat penyelesaian proses pendidikan, menghasilkan jumlah lulusan yang berkualitas serta memperkecil pemborosan, memberikan kesempatan berprestasi sehingga dapat menimbulkan dorongan psikologis untuk meningkatkan dedikasi serta pemanfaatan potensi yang dimiliki dalam meningkatkan kinerjanya.

Perilaku dan sikap pemimpin yang baik akan menginspirasi para guru yang tercermin dari kepribadian serta kemampuan guru dalam melakasanakan KBM yang diwujudkan melalui penguasaan kompetensi profesionalisme hubungan dengan rekan kerja. Menciptakan hubungan kerja yang serasi dan dinamis dalam bekerja akan meningkatkan harkat dan martabat tenaga pendidik dan kependidikan sehingga mendorong terwujudnya jiwa yang berdedikasi dalam upaya peningkatan kinerjanya

\section{Penilaian Kinerja}

Hasil penilaian kinerja guru diharapkan dapat bermanfaat untuk menentukan berbagai kebijakan yang terkait dengan peningatan mutu dan inerja guru sebagai ujung tombak pelaksanaan proses pendidikan dalam menciptakan insan yang cerdas, komprehensif, dan berdaya saing tinggi. Penilaian kinerja guru merupakan acuan bagi sekolah/madrasah untuk menetapkan pengembangan karir dan promosi guru. Bagi guru, penilaian kinerja guru merupakan pedoman untuk mengetahui unsurunsur kinerja yang dinilai dan merupakan saranan untuk mengetahui kekuatan dan kelemahan individu dalam rangka memperbaiki kualitas kinerjanya.

Beberapa tujuan penilaian kinerja yang dilakukan terhadap guru berenaan dengan: (Priansa, 2014: 356-358)
1. Peningkatan
Kinerja
(Performance

Improvement). Memungkinkan Dinas Pendidikan untuk melakukan evaluasi terhadap kinerja guru, dengan demikian Dinas Pendidikan dapat mengambil kebijakan yang berhubungan dengan peningkatan kinerja guru, hal tersebut penting dalam rangka meningkatkan inerja dan kualitas sekolah;

2. Penyesuaian Kompensasi (Compensation Adjusment). Hasil penilaian kinerja akan memberikan gambaran mengenai kelayakan kompensasi tambahan yang diperoleh guru. Biasanya untuk pendidikan kejuruan pada level SMK;

3. Keputusan Penempatan (Placement Decision) Dinas pendidikan dapat menentukan promosi, transfer, dan demosi yang dilakuan terhadap guru sesuai dengan kinerja yang ditampilkannya.

4. Kebutuhan Pengembangan dan Pelatihan (Training Development Needs) Kebutuhan pengembangan dan pelatihan bagi guru dapat dipetakandari hasil penilaian kinerja guru. Dengan demikian maka program pengembangan dan pelatihan bagi guru akan sesuai dengan kebutuhan guru.

5. Perencanaan dan Pengembangan Karir (Carrier Planning and Development) Hasil penilaian inerja akan memandu Dinas Pendidikan untuk menentukan jenis karir dan potensi karir yang dapat dicapai oleh guru sesuai dengan senioritas dan kompetensi yang dimiliinya.

6. Prosedur Perekrutan (Process Deficiencies) Mempengaruhi prosedur perekrutan guru yang berlaku di sekolah, sesuai dengan kepentingan sekolah dan supervisi dari Dinas Pendidikan.

7. Kesalahan Desain Pekerjaan dan Ketidakakuratan Informasi (Informational Inaccuracies and Job-Design Errors). Penilaian kinerja membantu menjelaskan apa saja kelemahan dalam desain pekerjaan yang diemban oleh guru serta memberikan masukan terkait dengan perbaikan informasi yang digunakan dalam rangka meningkatkan kinerja guru.

8. Kesempatan yang Sama (Equal Employment Opportunity) 


\section{Kepemimpinan}

Kepemimpinan adalah kemampuan meyakinkan dan menggerakkan orang lain agar mau bekerja sama dibawah kepemimpinannya sebagai suatu tim untuk mencapai suatu tujuan tertentu (Sadili, 2006: 287). Istilah kepemimpinan (leadership) adalah kata yang diambil dari kosa kata yang umum dipakai dan dimasukkan e dalam kosa kata teknis bidang ilmu tertentu tanpa didefinisikan kembali secara tepat (Gary Yuki, 2015: 2). Gaya kepemimpinan seorang pemimpin adalah unik dan tidak dapat diwariskan secara otomatis. Setiap pemimpin memiliki karakteristik tertentu yang timbul pada situasi yang berbeda. Kepemimpinan merupakan aspek pokok dalam pencapaian tujuan organisasi. Kepemimpinan adalah: "Leadership is the process of influencing the activities of individuals or organized groups so that they follow and do willingly what the leader wants them to do". (Marie Dalton, 2011: 234)

Kepemimpinan adalah proses mempengaruhi kegiatan individu atau kelompok terorganisir sehingga mereka rela mengikuti dan melakukan apayang pemimpin perintahkan. Pada setiap organisasi atau kelompok selalu mempunyai pemimpin dan apabila suatu kelompok tidak ada pemimpin, kegiatan yang dilakukan tidak akan terarah. Pemimpin ialah seorang yang mempunyai bawahan dan mempunyai kemampuan untuk mempengaruhi bawahan. Pengaruh positif pemimpin akan menjadi acuan bagi pengikutnya.

Kepemimpinan adalah: "leadership as the ability to inspire confi dence and support among the people who are needed to achieve organizationalgoals". (Adrew, 2010: 3). Kepemimpinan sebagai kemampuan untuk menginspirasi, kerahasiaan dan dukungan di antara orang- orang yangdiperlukan untuk mencapai tujuan organisasi. (Durbin, 2010: 3). Pemimpin yang ideal adalah sosok yang mampu menginspirasi dan memberikan pengaruh positif pada bawahannya. Inspirasi kepala sekolah menjadi penggerak dalam organisasi untuk mengendalikan pengikut supaya memiliki etos kerja yang berkualitas. Dukungan pimpinan dapat menimbulkan semangat dalam berkerja dan perubahan positif dalam diri pegawai. Inspirasi pemimpin menjadi penggerak dalam organisasi untuk mengendalikan bawahannya supaya memiliki etos kerja yang berkualitas. Disamping itu pimpinan memiliki kemampuan menjaga kerahasiaan informasi manajemen organisasi dan pegawai.

Leadership refers to the process of influencing the activities of others toward high levels of goal setting and achievement. ,yang artinya Kepemimpinan mengacu pada proses mempengaruhi kegiatan lain menuju tingkat tinggi penetapan tujuan dan prestasi. (David Body, 2009: 458) Agar dapat mengarahkan orang lain, pemimpin harus mengetahui bagaimana cara mendapat kekuasaan dan pengaruh, yang digunakan untuk mengarahkan orang lain. Kekuasaan melibatkan kemampuan mempengaruhi dalam mencapai suatu tujuan sesuai dengan apa yang diharapkan. Kekuasaan berkaitan dengan organisasi dan kepemimpinan dimana organisasi adalah wadah yang memiliki struktur, sehingga terdapat seorang pemimpin sebagai atasan yang memiliki kekuasaan dan yang dipimpin sebagai bawahannya sedangkan kekuasaan adalah kualitas yang melekat dalam satu interaksi antara dua atau lebih individu

Leadership The process of influencingpeople to direct their efforts toward theachievement of someparticular goal or goals. ArtinyaKepemimpinan Proses mempengaruhi orang untuk mengarahkan upaya mereka terhadap pencapaian beberapa tujuan atau tujuan tertentu . (Fred Luthan dan Jonathan, 2012: 456)

Beberapa hal yang terkait dengan prinsip kepemimpinan adalah: 1) Kepemimpinan tidak sama dengan manajer, 2) Kepemimpinan merupakan konsep yang rumit, 3) Atribut kepemimpinan dapat dibentuk melalui pengalaman, pelatihan dan analisa; 4) Keefektifan kepemimpinan tergantung terutama pada kesesuaian antara pemimpin, pengikut dan situasinya; 5) kepemimpinan disubstitusikan dalam berbagai pengaturan dan situasi, yaitu dalam beberapa situasi kepemimpinan bukanlah suatu pengaruh yang signifikan. 
Suatu perbedaan antara pemimpin dan manajer. Pemimpin siap menyimpan jawaban terhadap masalah yang mungkin rumit dan kompleks. Manajer adalah orang yang akan mencari keteraturan dan pengendalian serta memiliki kebiasaan untuk membuang masalah bahkan sebelum mereka memahami signifikansinya. Usaha mempengaruhi dalam suatu kelompok atau organisasi bukan hal yang mudah dilakukan. Hal itu dapat terlihat ketika pemimpin memberi tugas kepada bawahannya. Tugas yang diterima boleh saja tidak langsung dikejakan, bahkan dapat saja bawahan menyanggah dulu baru bekerja. Masalah seperti ini terjadi jika bawahan merasa kurang diperhatikan, atau tugas yang diperintahkan lebih menguntungkan pemimpin, atau untuk kepentingan pemimpin.

Leadership is the process of directing the behavior of others toward the accomplishment of some objective, yang artinya Kepemimpinan adalah proses mengarahkan perilaku orang lain menuju pencapaian beberapa tujuan. (Samuel C. Certo, 2012: 370

\section{Gaya Kepemimpinan}

Gaya kepemimpinan merupakan perilaku atau tindakan yang diambil oleh pemimpin ketika dia bekerja dan dapat menjadi gambaran penilaian baik buruknya apa yang dilakukan pemimpin. Cara bertindak dari pimpinan sangat terkait dengan hadirnya gaya kepemimpinan. Dalam melakukan kegiatan mempengaruhi, menggerakan atau memberikan motivasi kepada bawahannya, berbagai cara dapat dilakukan oleh pemimpin seperti melakukan tindakan- tindakan yang selalu konsisten pada pencapaian tujuan organisasi.

Gaya kepemimpinan merupakan cara yang digunakan dalam proses kepemimpinan yang diimplementasikan dalam perilakukepemimpinan seseorang dalam mempengaruhi orang lain untuk bertindak sesuai dengan apa yang pemimpin tersebut inginkan (Dimyanti, 2014: 71). Gaya kepemimpinan yang ideal adalah gaya yang secara aktif melibatkan bawahan dalam penetapan tujuan dengan menggunakan teknikteknik manajemen partisipatif dan memusatkan perhatian baik terhadap karyawan dan tugas (Dimyanti, 2014: 71). Dengan demikian dapat dipahami bahwa gaya kepemimpinan merupakan wujud proses mempengaruhi yang dilakukan pemimpin yang didasarkan pada norma perilaku dan digunakan untuk mencoba mempengaruhi perilaku orang lain.

Terdapat sejumlah gaya kepemimpinan yang dikenal. Sebagaimana diungkapkan:(Dimyanti, 2014:71), Univesity of Iowa Studies menyebutkan 4 (empat) jenis gaya kepemimpinan, yakni gaya kepemimpinan diktator/otoriter, gaya kepemimpinan autokratis, gaya kepemimpinan demokratis/partisipatif, dan gaya kepemimpinan laissez-Faire (kendali bebas). Selain itu terdapat gaya kepemimpinan yang melayani (servant leadership) yang diperkenalkan oleh Robert K. Greenleaf (1990) sebagaimana dikutif Stone, et al (2004: 352).

Berikut ini adalah uraian masingmasing gaya kepemimpinan tersebut

1. Gaya kepemimpinan diktator/otoriter merupakan gaya kepemimpinan yangmemusatkan segala keputusan dan kebijakan pada diri pemimpin secara penuh. Pemimpin mengendalikan semua aspek kegiatan, memberitahukan sasaran yang hendak dicapai, juga menyampaikan cara mencapai sasaran tersebut.

2. Gaya kepemimpinan autokratis merupakan gaya kepemimpinan yang menggunakan metode pendekatan kekuasaan dalam mencapai keputusan dan pengembangan strukturnya, sehingga kekuasaanlah yang paling diuntungkan dalam organisasi.

3. Gaya kepemimpinan demokratis/partisipatif merupakan pemimpin yang cenderung menyertakan karyawan dalam pengambilan keputusan, mendelegasikan kekuasaan, mendorong partisipasi karyawan dalam menentukan metode kerja dan tujuan yang hendak dicapai, dan memandang umpan balik sebagai kesempatan untuk melatih karyawan (Dimyati, 2014:74). Ciri-ciri kepemimpinan demokratis: (i) semua kebijakan terjadi pada kelompok diskusi. Keputusan diambil dengan dorongan dan bantuan pemimpin, (ii) kegiatan-kegiatan 
didiskusikan, dan (iii) para anggota bebas bekerja dengan siapa saja. Pembagian tugas ditentukamn oleh kelompok

4. Gaya kepemimpinan kendali bebas (lassesfaire) merupakan gaya kepemimpinan yang secara keseluruhan memberikan kebebasan pada karyawan atau kelompok dalam pembuatan keputusan dan menyelesaikan pekerjaan menurut cara karyawannya (Dimyati, 2014:75). Ciri-ciri kepemimpinan kendali bebas: (i) kebebasan penuh bagi keputusan kelompok atau individu dengan partisipasi mimnimal dari pemimpin, (ii) bahan-bahan yang bermacam-macam disediakan oleh pemimpin yang membuat setiap anggota selalu siap apabila dia akan memberikan informasi pada saat ditanya, (iii) dalam menentukan tugas, sama sekali tidak ada partisipasi dari pemimpin, dan (iv) pemimpin terkadang memberikan komentar spontan terhadap kegiatan anggota atau pertanyaan dan tidak bermaksud menilai atau mengatur suatu kejadian (Dimyati, 2014: 75).

Gaya kepemimpinan yang melayani (servant leadership) diperkenalkan oleh Robert K. Greenleaf di antara para teoritisi modern. Kepemimpinan mesti cocok dengan kebutuhan yang dipimpinnya. Fokus dari kepemimpinan yang melayani (servant leadership) adalah terhadap yang dipimpin daripada fokus terhadap dirinya, dan memahami peran pemimpin sebagai seorang pelayan (Stone, 2004: 352).

Tujuan utama servant leadership adalah untuk melayani dan memenuhi kebutuhan pihak yang lain, yang secara optimal seharusnya menjadi motivasi utama dalam kepemimpinan (Stone, 2004:352). Servant leadership mengembangkan orang, membantu mereka untuk berusaha dan berkembang, menciptakan visi, mendapatkan kredibilitas dan kepercayaan diri dari pengikutnya, dan memperoleh pengaruh dari orang lain (Stone, 2004: 352).

Fokus gaya kepemimpinan melayani adalah hubungan antara pemimpin dan pengikut berorientasi pada sifat melayani dengan standar moral. Pemimpin melayani mempunyai tanggung jawab untuk melayani kepentingan pengikut agar mereka menjadi lebih sejahtera, sebaliknya para pengikut memiliki komitmen penuh dalam bekerja untuk mencapai tujuan organisasi dan keberhasilan pemimpin. Kepemimpinan yang melayani dapat diterapkan pada semua bidang profesi, organisasi, lembaga, perusahaan (bisnis) dan pemerintahan karena kepelayanan bersifat universal.

\section{Kepuasan Kerja}

Istilah kepuasan kerja menjelaskan perasaan positif tentang sebuah pekerjaan, yang berasal dari evaluasi atas karakteristiknya. Seseorang dengan tingkat kepuasan kerja yang tinggi memiliki perasaan yang positif tentang pekerjaannya.

Job Satisfaction A positive attitude toward one's job is called job satisfaction. Ingeneral, people experience this attitude when their work matches their needs andinterests, when working conditions and rewards (such as pay) are satisfactory, whenthey like their coworkers, and when they have positive relationships with supervisors, yang artinya kepuasan kerja adalah sebuah sikap positif terhadap pekerjaan seseorang(Richard L. Daft, 2010: 380).

Job satisfaction, an attitude refl ecting a person's positive and negative feelings toward a job, co-workers, and the work environment. Indeed, you should remember that helping others realize job satisfaction is considered one hallmark of eff ective team leaders and managers-those who create work environments in which people achieve high performance and experience high job satisfaction yang artinya kepuasan kerj, sikap yang mencerminkan perasaan positif dan negatif seseorang terhadap pekerjaan, rekan kerja, dan lingkungan kerja (Mary Uhl-Bien, 2014: 84).

Job satisfaction is "a pleasurable feeling that results from the perception that one's job fulfills or allows for the fulfillment of one's important job values yang artinya Kepuasan kerja adalah perasaan menyenangkan yang dihasilkan dari persepsi bahwa pekerjaan seseorang memenuhi atau memungkinkan untuk pemenuhan nilai-nilai pekerjaan penting 
seseorang. (John A. Wagner III dan John R. Hollenbeck, 2010: 106)

Teori kepuasan kerja dua faktor (Two factortheory) memberikan perbedaan tentang kepuasan kerja dan ketidak-puasan kerja, selain itu teori ini merumuskan karateristik pekerjaan menjadi dua kelompok yaitu yang dinamakan faktor pemuas (motivation factor) atau yang disebut dengan satisfier atau intrinsic motivation dan faktor dissatisfies (Rivai \& Ella Jawani Sagala,2009: 856). Faktor satisfier merupakan fakor pendorong individu untuk berprestasi yang bersumber dari dalam diri individu tersebut antara lain: (1) pekerjaan yang menarik penuh tantangan (2) ada kesempatan berprestasi (3) kesempatan memperoleh penghargaan dan promosi. Faktor dissatisfies adalah faktor yang menjadi sumber ketidakpuasan, yang terdiri dari (1) gaji, (2) pengawasan, (3) hubungan antara pribadi, (4) kondisi kerja dan (5) status. Faktor-faktor ini merupakan faktor yangmenjadi kebutuhan dasar individu. Jika tidak terpenuhi faktor ini karyawan tidak akan puas, namun jika besarnya faktor ini memadai untuk memnuhi kebutuhan tersebut, karyawan tidak akan kecewa meskipun belum terpuaskan

\section{Metodologi Penelitian}

Penelitian ini menggunakan pendekatan kuantitatif, dengan memakai regresi linear sederhana dan berganda. Populasi pada penelitian ini adalah keseluruhan guru ASN pada SMP Negeri Kecamatan Setu Kabupaten Bekasi yang terdiri dari enam (6) SMP Negeri dengan jumlah guru yang berstatus Aparatur Negeri Sipil (ASN) enam puluh (60). Teknik pengambilan sampel menggunakan rumus slovin didasarkan jumlah populasi telah diketahui sebanyak 60 orang, maka ditarik sampel sebesar 38 orang dengan tingkat presisi 0,05

\section{HASIL PENELITIAN DAN PEMBAHASAN}

\author{
Uji Validitas Kepemimpinan, Kepuasan \\ Kerja dan Kinerja Guru
}

Berdasarkan pengolahan data uji validitas 28 butir pernyataan kepemimpinan pada 20 responden di dapat hasil koefisien korelasi antara skor butir dan skor total bernilai positif di atas $>0,3$. Ini menjukkan bahwa uji validitas variabel kepemimpinan, kepuasaan kerja dan kinerja guru adalah valid.

\section{Uji Reliabilitas Kepemimpinan, Kepuasan Kerja dan Kinerja Guru}

Tabel 1

Nilai Crobach's Alpha pada Uji Reliabilitas

\begin{tabular}{|c|c|c|c|}
\hline Variabel & $\begin{array}{c}\text { Cronbach's } \\
\text { Alpha }\end{array}$ & Standard & Keterangan \\
\hline Kepeminpinan & 0,754 & $>0,6$ & Reliabel \\
\hline Kepuasan & 0,756 & $>0,6$ & Reliabel \\
\hline Kinerja & 0,746 & $>0,6$ & Reliabel \\
\hline
\end{tabular}

Sumber: Hasil Output SPSS

Hasil output analisis yang telah dilakukan pada 20 responden maka dapat dilihat nilai Cronbach's Alpha pada masingmasing variabel lebih besar dari standar yang ditentukan $>0,6$.

\section{Uji Normalitas Kepemimpinan, Kepuasan Kerja dan Kinerja Guru}

Tabel 2.

Uji Normalitas Kepemimpinan

\begin{tabular}{|c|c|c|}
\hline & & RESIDUAL \\
\hline $\mathrm{N}$ & & 38 \\
\hline \multirow[t]{2}{*}{ Normal Parameters $2, b$} & Mean & 1.8158 \\
\hline & Std. Deviation & 9.26373 \\
\hline \multirow[t]{3}{*}{ Most Extreme Differences } & Absolute & .124 \\
\hline & Positive & .124 \\
\hline & Negative & -.093 \\
\hline \multicolumn{2}{|l|}{ Test Statistic } & .124 \\
\hline \multicolumn{2}{|l|}{ Asymp. Sig. (2-tailed) } & $.144^{\circ}$ \\
\hline \multicolumn{3}{|l|}{ a. Test distribution is Normal. } \\
\hline \multicolumn{3}{|l|}{ b. Calculated from data. } \\
\hline \multicolumn{3}{|c|}{ c. Lilliefors Significance Correction. } \\
\hline \multicolumn{3}{|c|}{ Sumber: Hasil Output SPSS } \\
\hline
\end{tabular}

Hasil penghitungan statistik Kolmogorov Smirnov, sebagaimana tampak dalam Tabel 2 didapatkan nilai sig pada $(\alpha=0,05)=0,144$. Dengan demikian 0,144>0,05 dan dapat dikemukakan bahwa distribusi data 
Kepemimpinan (X1) berasal dari populasi yang berdistribusi normal.

Tabel 3.

Uji Normalitas Kepuasan Kerja

\begin{tabular}{|c|c|c|}
\hline & & RESIDUAL \\
\hline $\mathrm{N}$ & & 38 \\
\hline \multirow[t]{2}{*}{ Normal Parameters ${ }^{a, b}$} & Mean & -2.6842 \\
\hline & Std. Deviation & 6.98361 \\
\hline \multirow[t]{3}{*}{ Most Extreme Differences } & Absolute & .135 \\
\hline & Positive & .135 \\
\hline & Negative & -.076 \\
\hline Test Statistic & & .135 \\
\hline Asymp. Sig. (2-tailed) & & $.076^{\mathrm{c}}$ \\
\hline
\end{tabular}

Sumber: Hasil Output SPSS

Hasil penghitungan statistik Kolmogorov Smirnov, sebagaimana tampak dalam Tabel 4.13 didapatkan nilai sig pada $(\alpha=0,05)=0,76$. Dengan demikian $0,76>0,05$ dan dapat dikemukakan bahwa distribusi data Kepuasan Kerja $\left(\mathrm{X}_{2}\right)$ berasal dari populasi yang terdistribusi secara normal.

Tabel 4.

Uji Normalitas Kinerja Guru

\begin{tabular}{|c|c|c|}
\hline \multicolumn{2}{|c|}{ One-Sample Kolmogorov-Smirnov Test } & RESIDUAL \\
\hline $\mathrm{N}$ & & 38 \\
\hline Normal & Mean & .0000 \\
\hline Parametersa,b & Std. Deviation & 9.23345 \\
\hline Most Extreme & Absolute & .102 \\
\hline Differences & Positive & .102 \\
\hline & Negative & -.055 \\
\hline Test Statistic & & .102 \\
\hline Asymp. Sig. (2 & & $.200^{\mathrm{c}, \mathrm{d}}$ \\
\hline
\end{tabular}

a. Test distribution is Normal.

b. Calculated from data.

c. Lilliefors Significance Correction.

d. This is a lower bound of the true significance.

Sumber: Hasil Output SPSS

$$
\text { Hasil penghitungan statistik }
$$

Kolmogorov Smirnov, sebagaimana tampak dalam Tabel 4.13 didapatkan nilai sig pada $(\alpha=0,05)=0,200$. Dengan demikian 0,200 >0,05 dan dapat dikemukakan bahwa distribusi kinerja guru (Y) berasal dari populasi yang berdistribusi normal.

\section{Koefisien Determinasi $\left(\mathrm{R}^{2}\right)$}

Koefisien determinasi didapat dari hasil olah data SPSS dari regresi linier berganda. Berdasarkan hasil olah data dari 38 observasi yang dilakukan dalam penelitian ini didapat nila $\mathrm{R}^{2}$ koefisien determinasi seperti dalam tabel 5 di bawah ini.

Tabel 5.

Koefisien Determinasi

\begin{tabular}{l|c|c|r|r|r|}
\hline Model & $\mathrm{R}$ & R Square & $\begin{array}{c}\text { Adjusted R } \\
\text { Square }\end{array}$ & $\begin{array}{c}\text { Std. Error of } \\
\text { the Estimate }\end{array}$ & $\begin{array}{c}\text { Durbin- } \\
\text { Watson }\end{array}$ \\
\hline 1 & $.736^{\mathrm{a}}$ & .542 & .516 & 9.906 & 1.890 \\
\hline
\end{tabular}
a. Predictors: (Constant), X2, X1
b. Dependent Variable: Y Sumber:

Sumber: Hasil Output SPSS

Berdasarkan tabel diperoleh bahwasanya nilai koefisien korelasi $\mathrm{R}^{2}=0,542$ artinya variabel Kepemimpinan dan Kepuasan Kerja Guru mempengaruhi Kinerja Guru sebesar 0,542 dan 0,458 dipengaruhi oleh variabel lain yang tidak diteliti. Nilai koefisien determinasi lebih 0,5 menunjukan bahwa model regresi dapat menjelaskan pengaruh kepemimpinan dan kepuasan kerja terhadap kinerja guru dengan cukup baik.

\section{Uji Simultan (Uji F-Statistic)}

Uji simultan dilakukan untuk mengetahui apakah Hipotesis 3 mendukung atau tidak. Uji ini untuk mengetahui apakah variabel kepemimpinan dan kepuasan kerja guru secara bersama mempengaruhi variabel kinerja

Tabel 6.

Uji Simultan (Uji F-Statistic)

\begin{tabular}{|c|c|c|c|c|c|}
\hline \multicolumn{6}{|c|}{ ANOVA $^{\mathrm{a}}$} \\
\hline Model & $\begin{array}{l}\text { Sum of } \\
\text { Squares }\end{array}$ & $\mathrm{df}$ & $\begin{array}{c}\text { Mean } \\
\text { Square }\end{array}$ & F & Sig. \\
\hline \multirow{3}{*}{$\begin{array}{ll}1 & \text { Regression } \\
& \text { Residual } \\
& \text { Total } \\
\end{array}$} & 4061.156 & 2 & 2030.578 & 20.694 & $.000^{\mathrm{b}}$ \\
\hline & 3434.318 & 35 & 98.123 & & \\
\hline & 7495.474 & 37 & & & \\
\hline
\end{tabular}

Sumber: Hasil Output SPSS

Hasil output pada tabel menunjukkan nilai F sebesar 20,694 dengan signifikansi 0,000 $<0,05$, artinya variabel kepemimpinan dan kepuasan kerja guru bersama-sama berpengaruh terhadap kinerja guru di Sekolah 
Menengah Pertama Negeri 5. Rumusan $\mathrm{H}_{0}$ : Tidak terdapat pengaruh signifikan kepemimpinan dan kepuasan kerja guru secara bersama-sama terhadap kinerja; Ha: Terdapat pengaruh signifikan kepemimpinan dan kepuasan kerja guru secara bersama-sama terhadap kinerja. DF1 = k-1 = 2-1=1; DF2 $=\mathrm{N}-\mathrm{k}$ $=38-2$ =36; maka Ftabel didapat 4,11. Karena F hitung 20,694 > 4,11 dapat disimpulkan Ho ditolak dan $\mathrm{Ha}$ diterima, artinya terdapat pengaruh kepemimpinan dan kepuasan k\&r4a1 guru secara simultan terhadap kinerja guru. Hipotesis ini terdukung bahwa kepemimpinan dan kepuasan kerja guru berpengaruh positif terhadap kinerja guru di Sekolah Menengah Pertama Negeri.

\section{Uji Hipotesis Pengaruh Kepemimpinan Terhadap Kinerja Guru}

Tabel 7.

Coefficient Regresi Linear Ganda X1 Terhadap Y

\begin{tabular}{|c|c|c|c|c|c|}
\hline \multirow[b]{2}{*}{ Model } & \multicolumn{2}{|c|}{$\begin{array}{l}\text { Unstandardized } \\
\text { Coefficients }\end{array}$} & \multirow{2}{*}{$\begin{array}{c}\begin{array}{c}\text { Standardized } \\
\text { Coefficients }\end{array} \\
\text { Beta } \\
\end{array}$} & \multirow[b]{2}{*}{$t$} & \multirow[b]{2}{*}{ Sig. } \\
\hline & B & Std. Error & & & \\
\hline \begin{tabular}{|ll}
1 & (Constant)
\end{tabular} & 25.131 & 13.264 & & 1.895 & .066 \\
\hline $\mathrm{X} 1$ & .384 & .113 & .457 & 3.383 & .002 \\
\hline $\mathrm{X} 2$ & .388 & .137 & .383 & 2.834 & .008 \\
\hline
\end{tabular}

Sumber: Hasil Output SPSS

Dari hasil output perhitungan analisis regresi linear dapat dibentuk model persamaan regresi dan signifikansi sebagai berikut:

$\mathrm{Y}=25,131+0,384 \mathrm{X} 1+0,388 \mathrm{X} 2+\mathrm{u}$

Intercept dalam model diatas sebesar 25,131 dan koefisien regresi X1 0,384 Dan koefisien X2 0,388. T-hitung variabel kepemimpinan pada tabel 4.19 sebesar 3,383 dan t-tabel sebesar 2,042, karena $\mathrm{t}$ hitung $>\mathrm{t}$ tabel atau 3,383 > 2,042, maka Ho ditolak dan Ha diterima, artinya terdapat pengaruh yang signifikan secara positif pada variabel kepemimpinan dan kepuasan kerja guru.

\section{Uji Hipotesis Pengaruh Kepuasan Kerja Guru Terhadap Kinerja Guru}

Tabel 7 menunjukan koefisien $t$ sebesar 2,83 Dengan signifikansi sebesar 0,008 atau sig $<0,05$. Fakta ini dapat disimpulkan terdapat pengaruh positif kepuasan kerja guru terhadap kinerja guru. karena $t$ hitung $>\mathrm{t}$ tabel atau 2,83 $>$ 2,042, maka Ho ditolak dan Ha diterima, artinya terdapat pengaruh yang signifikan secara positif pada variabel kepuasan kerja guru terhadap kinerja guru.

\section{PEMBAHASAN}

\section{Kepemimpinan berpengaruh langsung positif terhadap kinerja.}

Temuan dalam penelitian ini menunjukkan bahwa kepemimpinan berpengaruh langsung positif dan signifikan terhadap kinerja. Pengaruh langsung positif variabel kepemimpinan $\left(\mathrm{X}_{1}\right)$ terhadap kinerja $(\mathrm{Y})$ sebesar 0,384 dengan nilai koefesien $t_{\text {hitung }}$ sebesar 3,383 . Nilai koefesien $t_{\text {hitung }}$ lebih besar dari $t_{\text {tabel }}$ pada $\alpha$ 0,05 $=2,024$, .Fakta di atas menunjukann t-Hitung $>$ t-Tabeldengan demikian kepemimpinan $\left(\mathrm{X}_{1}\right)$ berpengaruh positif terhadap kinerja ( $\mathrm{Y}$ ) dinyatakan sangat signifikan.Besarnya pengaruh variabel kepemimpinan terhadap kinerja guru ditunjukan oleh $\mathrm{R}^{2}$ partial $\mathrm{X} 1$ terhadap $\mathrm{Y}$ yaitu sebesar 0,437 .

Penelitian ini difokuskan pada ruang lingkup kepemimpinan yang menunjukan bahwa variable kepemimpinan berpengaruh positif terhadap kinerja guru hal ini sesuai dengan pendapat yang dikatakan Soeijono Soekanto, menyatakan bahwa kepemimpinan adalah kemampuan pemimpin atau leader untuk mempengaruhi orang yang dipimpin atau pengikut-pengikutnya. Sehingga orang lain lersebut bertingkah laku sebagaimana dikehendaki oleh pemimpin tersebut bahwa kinerja dipengaruh oleh sikap kepemimpinan dapat mempengaruhi kinerja guru agar dapat melakukan pekerjaanya secara professional dan dapat menjadikan guru sebagai SDM yang berkualitas dalam melakukan pekerjaannya.

Selain itu juga adanya peran dari pemimpin yang mampu mengarahkan atau mendorong para karyawan untuk dapat bertindak secara sprofesional melahirkan kinerja yang baik.Implcmentasi gaya-gaya kepemimpinan di atas memberi pengaruh 
kepada bawahan dan bawahan merasa diperhatikan oleh atasannya, di bantu, dihimbing dan diberi dukungan sosial untuk menghadapi kesulitannya, dan hagaimana cara menyelesaikan pekerjaannya secara baik.

Hal ini sependapat dengan pendapat yang dikemukakan oleh A.Dale Timpe mengemukakan bahwa pemimpinlah yang menentukan kemana arah tujuan internal maupun tujuan ekstemal, dan menyelaraskan keterampilan organisasi dengan kesempatan dan resiko dipengaruhi oleh lingkungan.

Pemimpin adalah seorang yang mempengaruhi orang lain untuk mencapai tujuan. Makin besar pengaruh seorang pemimpin, makin besar pula pengikutnya.Dan makin sukses tujuan-tujuan yang dapat dicapai makin terbukti kepemimpinannya. Hal ini senada dengan Andrew J. DuBrin mengemukakan pendapat bahwa leadership The ability to inspire confidence and support among the people who are needed to achieve organizational goals, yang artinya Kepemimpinan adalah Kemampuan un:tA2 menginspirasi kepercayaan diri dan dukungan di antara orang- orang yang diperlukan untuk mencapai tujuan organisasi.

\section{Kepuasan kerja berpengaruh langsung positif terhadap kinerja.}

Temuan dalam penelitian ini menunjukkan bahwa kepuasan kerja berpengaruh langsung positif dan sangat signifikan terhadap kinerja. Pengaruh langsung positif variabel kepuasan kerja $\left(\mathrm{X}_{2}\right)$ terhadap kinerja (Y) sebesar 0,388 dengan nilai koefesien $t_{\text {hitung }}$ sebesar 2,834 . Nilai koefesien $t_{\text {hitung }}$ lebih besar dari $t_{\text {tabel }}$ pada pda $\alpha 0,05$ dengan demikian dapat disimpulkan kepuasan kerja $\left(\mathrm{X}_{2}\right)$ berpengaruh langsung positif terhadap kinerja (Y) dinyatakan signifikan. Besarnya pengaruh variabel kepuasan kerja terhadap kinerja guru sebesar 0,397.

Istilah kepuasan kerja menjelaskan perasaan positif tentang sebuah pekerjaan, yang berasal dari evaluasi atas karakteristiknya. Seseorang dengan tingkat kepuasan kerja yang tinggi memiliki perasaan yang positif tentang pekerjaannya, sementara seseorang yang tidak puas mempunyai perasaan yang negative

Orang dapat lebih puas dengan konfigurasi kerja tertentu dari pada dengan yang lainnya, penting untuk mampu mengidentifikasi apa yang membuat pekerjaan "bagus" dalam pengertiannya yang paling dasar. Prestasi mengarah pada kepuasan dari pada kepuasan mengarah pada bentuk kerja prestasi yang bisa mempengaruhi kepuasan kerja

Kepuasan berpengaruh terhadap kinerja sependapat dengan Menurut Schermerhorn secara formal kepuasan kerja didefenisikan sebagai tingkatan dimana individu merasa secara positif atau negatif tentang pekerjaan mereka. (job satisfactionis the degree to which individuals feel positively or negatively about their jobs) Ini adalah respon sikap atau emosi terhadap tugas-tugas seseorang sama halnya juga terhadap kondisi fisik dan sosial tempat bekerja.

\section{Kepemimpinan dan Kepuasan kerja berpengaruh langsung positif terhadap kinerja}

Temuan dalam penelitian ini menunjukkan bahwa kepemimpinan dan kepuasan kerja secara bersama-sama berpengaruh langsung positif dan signifikan terhadap kinerja. Pengaruh langsung positif variabel kepemimpinan $\left(\mathrm{X}_{1}\right)$ dan kepuasan kerja $\left(\mathrm{X}_{2}\right)$ terhadap kinerja $(\mathrm{Y})$ sebesar 0,542 dengan nilai koefesien $F_{\text {hitung }}$ sebesar 20,694 Nilai koefesien $t_{\text {hitung }}$ lebih besar dari $t_{\text {tabel }}$ pada alfa $\alpha$ 0,05 yaitu 2,042dengan demikian dapat disimpulkan kepuasan kerja $\left(\mathrm{X}_{2}\right)$ berpengaruh langsung positif terhadap kinerja (Y) dinyatakan signifikan.

Pengaruh gaya kepemimpinan dan kepuasan kerja terhada kinerja guru akam memberi kontribusi terhadap kualitas profesionalisme guru yaitu berupa meningkatnya kemampuan guru dalam melasanakan kegiatan belajar mengajar dan pencapaian hasil akan terlihat pada pencapaian hasil belajar peserta didik dan pembentukan karakter peserta didik yang berorientasi kepada pencapaian tujuan organisasi sekolah dan tujuan pendidikan nasional.Dari penjelasan 
di atas menunjukan bahwa Hipotesis 3 terdukung secara positif.

\section{KESIMPULAN}

Berdasarkan hasil penelitian tentang kinerja guru SMP Negeri Kecamatan Setu Kabupaten Bekasi, maka diperoleh kesimpulan sebagai berikut, bahwa terdapat pengaruh positif gaya kepemimpinan terhadap kinerja guru SMP Negeri, artinya peningkatan intensitas perilaku atau cara bertindak pemimpin dalam proses mempengaruhi, mengarahkan, menginspirasi, memotivasi dan mengkordinasi guru serta menyelenggarakan program-program peningkatan kompetensi guru akan mengakibatkan peningkatan kinerja guru ASN SMP Negeri. Terdapat pengaruh positif kepuasan kerja terhadap kinerja guru SMP Negeri. Artinya peningkatan intensitas kepuasan kerja akan mengakibatkan peningkatan kinerja guru SMP Negeri. Terdapat pengaruh positif secara bersama-sama antara gaya kepemimpinan dan kepuasan kerja terhadap kinerja guru ASN SMP Negeri;

\section{SARAN}

Berdasarkan kesimpulan hasi
penelitian dan implikasi penelitian disampaikan saran penelitian yaitu bahwa cara bertindak (gaya) kepemimpinan kepala sekolah hendaknya dapat merancang dan menyusun program kerja untuk meningkatkan kemampuan dan keterampilan guru ASN SMPN yang masih dirasakan kurang, kemudian memprioritaskan kegitan tersebut kepada guru secara adil agar kemampuan profesionalisme guru merata dan semakin meningkat, kemudian menyusun program pelatihan dan keterampilan secara rinci termasuk anggarannya, melaksanakan evaluasi setiap aktivitas pelatihan, dan menyiapkan media, sarana dan prasarana pembelajaran yang memadai sehingga tercipta kepuasan guru melaksanakan tugas.

Kinerja guru ASN SMP Negeri yang berkaitan dengan kepemimpinan dan pengenalan kepuasan kerja guru ASN SMP Negeri merupakan salah satu faktor penentu meningkatnya kinerja guru atau prestasi guru, dan berdasarkan hasil penelitian, kedua variabel ini mempengaruhi Kinerja guru SMP Negeri Kecamatan Setu dan hendaknya guru ASN SMP Negeri membangun sifat positif terhadap hasil kerja serta memandang kerjanya sebagai nilai ibadah yang ikhlas dan melakukan Kinerja dan bertanggung jawab sesuai tugas pokok dan fungsinya sertra motivasi kerja guru SMP Negeri datang dari dalam diri, sehingga mereka mampu untuk melaksanakan tugas sesuai dengan apa yang sudah tertulis dalam kode etik guru dalam rangka menungkatkan mutu pendidikan.

\section{Daftar Pustaka}

Alamsyah, D. P., Suhartini, T., Rahayu, Y., Setyawati, I., \& Hariyanto, O. I. B. (2018, November). Green advertising, green brand image and green awareness for environmental products. In IOP Conference Series: Materials Science and Engineering (Vol. 434, No. 1, p. 012160). IOP Publishing.

Bien, Mary Uhl. Organizational Behavior. 13rd edition. New York: 2014.

Body, David. 2009. Management : an introduction 4th edition. Spain: 2009.

Certo, Samuel C. Modern management: concepts and skills12th ed. New Jarsey: 2012.

Dalton, Marie, Dawn Hoyle, and MarieWatts. Human Relations, Fourth Edition. California, 2011.

Dimyati, Hamdani. Model Kepemimpinan dan Sistem Pengambilan Keputusan. Bandung: Pustaka Setia, 2014.

Draft, Richard L. with the assistance ofPatricia G. Lane. Management, Ninth Edition. South-Western: 2010.

DuBrin, Andrew J. 2012. Essentials of Management, Ninth Edition. SouthWestern: 2012.

DuBrin, Andrew. Leadership: Research Findings, Practiceand Skills, Sixth Edition. SouthWestern: 2010.

George, Jennifer M. dan Gareth Jones. Understanding and managing organizational behavior. 6th ed. New Jersey: 2012.

Ghozali, Imam. 2012. Aplikasi Analisis Multivariate dengan Program SPSS 20. 
63 | Pengaruh Kepemimpinan Dan Kepuasan Kerja Terhadap Kinerja Guru SMP Negeri Kecamatan Setu

Kabupaten Bekasi oleh Rita Zusana Lantu dan Tungga Buana Irfana

Cetakan VI. Badan Penerbit: Universitas Diponegoro, Semarang.

Gibson, James L. Organizations : behavior, structure, processes. New York: 2012.

Griffin, Ricky W. and Gregory Moorhead. Organizational Behavior. New York: 2014.

Managing People and Organizations, Eleventh Edition.Canada Hendraman. Revolusi Kinerja Kepala Sekolah. Jakarta, Penerbit Indeks, 2015.

Joko, Raharjo. Paradigma Baru Manajemen Sumber Daya Manusia. Jakarta: 2013.

Kenneth, Greg L. Stewart, G. Brown. Human Research Management Linking Strategy To Practice. New York: 2011.

Kuncoro, Mudrajad. Metode Kuantitatif: Teori dan Aplikasi untuk Bisnis \& Ekonomi.Edisi keempat. Yogyakarta: UPP STIM YKPN, 2011.

Luthan, Fred dan Jonathan. International management : culture, strategy, and behavior 8th ed. New York: 2012.

Luthans, Fred. Organizational behavior : an evidence-based approach 12th ed. New York: 2011.

Mullins, Laurie J. 2010. Management \& Organisational Behaviour. Ninth Edition.

Peraturan Menteri Nasional Nomor 16 Tahun 2004 tentang Standar Kualifikasi Akademik dan Kompetensi Guru, Pasal 1 ayat (1). Jakarta: 2004.

Peraturan Menteri Negara Pendayagunaan Aparatur Negara dan Reformasi Birokrasi Nomor 16 Tahun 2009. Jakarta: 2009.

Peraturan Pemerintah Nomor 19 Tahun 2005 tentang Standar Nasional Pendidikan. Jakarta: 2005.

Peraturan Pemerintah RI Nomor 74 Tahun 2008, pasal 2 tentang Guru. Jakarta: 2008.

Priansa, Donni Juni. Kinerja dan Profesionaloisme Guru. Bandung: Alfabeta, 2014.

Priansa, Donni Juni. Kinerja dan Profesionaloisme Guru. Bandung: Penerbit Alfabeta, 2014.
Rivai dan Ella Sagala. Manajemen Sumber Daya Manusia Untuk Perusahaan Dari Teori Ke Praktik. Jakarta: Cetakan ke-4. PT. Rajagrafindo Persada, . 2011.

Robbins, Stephen P., Mary Coulter. Management. 11th ed.America Robbins, Stephen P., Timothy A. Judge. 2013. Organizational behavior. 15th ed. New York: 2013.

Sandjaja dan Albertus Heriyanto. Panduan Penelitian. Jakarta: Prestasi Pustaka, 2011.

Setyawati, I. (2016). Determinants of Growth and Profitability by Bank Specific Variable and Market Stucture in Islamic Banking in Indonesia. Academy of Strategic Management Journal, 15, 1-14.

Setyawati, I. R. M. A., Kartini, D., Rachman, S., \& Febrian, E. (2015). Assessing the Islamic banking financial performance in Indonesia. International Journal of Education and Research, 3(10), 233-248.

Schermerhorn, John R., Jr. James G Hunt, Richard N. Osborn, Mary Uhl-Bien. Organizational Behavior. New York: 2010. 